\title{
POLA PENGEMBANGAN KEMANDIRAN KEWIRAUSAHAAN PONDOK PESANTREN BERBASIS SANTRI
}

\section{( Studi Kasus Pondok Pesantren Nurul Hakim Kediri Lombok Barat )}

\author{
Edi Irawan \\ Fakultas Ekonomi Dan Bisnis, Universitas Teknologi Sumbawa \\ *)e-mail :edi.irawan@uts.ac.id
}

\begin{abstract}
Abstrak
Pindidikan Pondok Pesantren menjadi pendidikan formal di Indonesia telah memberikan tantangan dan warna terhadap perkembangan pondok pesantren dan dunia pendidikan itu sendiri. Penelitian ini bertujuan untuk mengetahui metode pengembangan kemandirian kewirausahaan pesantren berbasis santri, faktor pendorong dan faktor penghambatnya, serta bentuk program dan manfaatnya bagi kemandirian pondok pesantren Nurul Hakim Kediri Lombok Barat dalam menghadapi tantangan yang ada.

Penelitian ini menggunakan metode kualitatif dengan metode pendekatan deskriptif. Hasil penelitian menunjukkan bahwa pondok pesantren Nurul Hakim mengembangkan metode pengembangan kemandirian kewirausahaan pesantren berbasis santri dengan beberapa kreavitasnya yaitu: Dewan santri sebagai penggerak program, Membentuk SMK plus Nurul Hakim, Program pengabdian alumni, Kurikulum khas dan pendidikan pengembangan kewirausahaan dan Koordinasi Buttom Up. Pengembangan kemandirian kewirausahan dilakukan karena tuntutan pendidikan, tuntutan untuk meringankan beban operasional dan tuntutan dakwah. Kemudian ada beberapa hambatan dalam menjalani program pengembangan kemandirian kewirausahan pesantren yaitu: manajemen dan sumber daya manusia. Namun demikian hasil program pengembangan kemandirian kewirausahaan pesantren sudah dirasakan manfaatnya untuk kemandirian santri dan masyarakat.
\end{abstract}

Kata Kunci: Pondok Pesantren,pengembangan kemandirian kewirausahan

\section{Pendahuluan}

Pondok pesantren adalah salah satu lembaga pendidikan di Indonesia yang telah sejak lama menerapkan pendidikan dan pemberdayaan. Salah satu ciri khusus pesantren menurut Armando (2005:296) adalah kehidupan mandiri dan senderhana. Hingga kini banyak penelitian yang membuktikan bahwa pesantren merupakan lembaga pendidikan yang mandiri dan khas Indonesia. Sejak kurang lebih 500 tahun yang lalu berbagai macam peran dalam masyarakat Indonesia. Nurcholis Majid ( dalam Yasmadi,2005:121) berobsesi menciptakan pondok pesantren menjadi suatu system pendidikan yang memiliki keterpaduan antara unsur keislaman, ke-Indonesiaan dan keilmuan guna mewujudkan masyarakat madani.

Proses pendidikan dan pembangunan tidak dapat dipisahkan, pendidikan harus diperhatikan guna tercapainya tujuan pembangunan nasional. Pendidikan nasional berfungsi mengembangkan kemampuan dan membentuk watak serta peradaban bangsa yang bermatabat dalam rangka mencerdaskan kehidupan bangsa, bertujuan untuk berkembangnya potensi peserta didik agar menjadikan manusia yang beriman dan bertakwa kepada Tuhan yang Maha Esa,berakhlak mulia, sehat, berilmu, cakap, kreatif , mandiri dan menjadi warga Negara yang demokratis serta bertanggung jawab (Malik, Jamaludin;2001).

Pendidikan formal di Indonesia banyak mengadopsi sistem pendidikan pada masa penjajahan dahulu. Sementara, ketika itu Indonesia sudah memiliki sistem pendidikan lokal yaitu pondok pesantren yang hingga kini tetap eksis dalam dunia pendidikan Indonesia. Pesantren, dalam perkembangannya, telah menjadi pusat kegiatan masyarakat dalam bidang pendidikan, sosial, kesehatan dan pelatihan ketrampilan melalui teknologi tepat guna.

Pesantren sebagai lembaga pendidikan tradisional dianggap efektif dalam menjalankan berbagai kegiatan salah satunya adalah kegiatan kewirausahaan yang berdaya saing khusus bagi komunitas pesantren itu sendiri. Hal ini disebabkan oleh intraksi yang intens antar santri dan diantara santri dengan kianya melalui melalui sistem pendidikan dan aktivitas keseharian yang sering dilalui bersama. Bahkan, Rian (2005) menyebutkan bahwa pesantren di pedasaan merupakan lembaga yang cukup potensial dalam mengembangkan capital sosial para anggota di dalamnya.

Pondok pesantren yang didiami oleh santri yang jumlahnya cukup banyak merupakan konsumen yang positif dan didukung oleh masyarakat sekitarnya. Artinya santri dan masyarakat sekeliling pada dasarnya adalah konsumen yang kebutuhannya dapat dicukupi secara ekonomi oleh pesantren itu sendiri. Jadi,pesantren hakekatnya bisa mandiri untuk menjadi pusat kelembagaan ekonomi, bagi warganya di dalam pesantren dan luar pesantren

Tantangan yang dihadapi pondok pesantren semakin besar hari semakin besar, kompleks dan mendesak, sebagai akibat meningkatnya kebutuhan pembangunan dan kemajauan pengetahuan dan teknologi. Tantangan ini menyebabkan terjadinya pergeseran - pergeseran nilai di pesantren, baik nilai yang menyangkut sumber belajar maupun nilai yang menyangkut pengelolaan pendidikan, pergeseran system dan metode belajar , serta pergeseran pengembangan fungsi kelembagaan pesantren itu sendiri ( Anas,2012: 95-96). 
Kemajuan sosial ekonomi sebuah pesantren tidak lepas dari peran santri, kiai dan para ustaz memiliki kekuasaan yang bersifat kharismatik yang mampu mengendalikan santri dalam melakukan kegiatan sosial ekonomi. Dalam mengurus usaha pertanian,usaha menjahit dan usaha las kiai sekedar memberikan bimbingan, selebihnya menjadi tanggung jawab santri. Bimbingan pendamping kewirausahaan bagi santri diperlukan guna mempersiapkan wirusaha yang berlandasan syariat Islam. Oleh sebab itu diperlukan modernisasi pendidikan kewirausahaan pesantren. Di pondok pesantren Nurul Hakim Kediri Lombok Barat santri juga dibekali dengan ilmu ketrampilan dalam berwirausaha seperti Ilmu ketrampilan menjahit untuk santri putri ,ketrampilan agribisnis , ketrampilan las dan otomotif serta jasa keuangan syariah untuk santri laki - laki. Keempat ketrampilan yang diprogramkan oleh pondok pesantren Nurul Hakim bertujuan yaitu untuk membekali para santri siap mandiri setelah lulus dari pondok pesantren di samping ilmu pokok agama yang mereka terapkan di kehidupan dan di tengah masyarakat. Jadi santri tidak hanya belajar kitab kuning, tetapi juga melakukan banyak hal karena memiliki waktu 24 jam di lingkungan pondok pesantren.

Berbeda dengan kebanyakan pesantren modern lainya yang mengenakan tarif mahal, pondok pesantren Nurul Hakim Kediri Lombok Barat justru juga menampung santri kurang mampu. Saat ini pondok Nurul Hakim Kediri Lombok Barat memiliki 4.791 santri dan sudah memiliki sarana dan prasarana yang cukup memadai dan semua sarana tersebut dibangun secara mandiri oleh santri dan dari donator baik dari dalam negeri maupun dari luar negeri.

Adapun permasalahan yang dikaji dalam penelitian ini adalah "bagaimana metode pengembangan kemandirian kewirausahaan pesantren berbasis santri di pondok Pesantren Nurul Hakim Kediri Lombok Barat?”

\section{Tujuan Penelitian}

Adapun tujuan penelitian ini ialah mengetahui metode, bentuk program pengembangan kemandirian kewirausahaan pesantren berbasis santri.

\section{Manfaat Penelitian}

Adapun manfaat dari penelitian ini yaitu:

a) Dapat meningkatkan kemampuan penulis dalam menulis karya ilmiah.

b) Sebagai arahan rekomendasi untuk pengembangan kemandirian kewirausahaan pesantren berbasis santri bagi pihak pondok pesantren Nurul Hakim Kediri Lombok Barat.

\section{Tinjaun Pustaka}

\section{Pengertian Kewirausahaan}

Kewirausahaan adalah semangat, sikap, perilaku dan kemampuan seseorang dalam menangani usaha dan atau kegiatan yang mengarah pada upaya mencari, menciptakan, menerapkan cara kerja, teknologi dan produk baru dengan meningkatkan efisiensi dalam rangka memberikan pelayanan yang baik dan atau memperoleh keuntungan yang lebih besar. (Soetojo,2014)
Sejalan dengan pengertian tersebut, maka yang dimaksud wirausaha adalah orang yang mempunyai semangat, sikap,prilaku dan kemampuan kewirausahaan. Pengusaha pengusaha yang tekun, kreatif, produktif dan berani mengambil resiko serta berhasil dalam usahanya jelas adalag wirausaha tetapi jelas pula tidak semua pengusaha dapat disebut wirausaha. (soetojo,2014)

\section{Asas Pokok Kewirausahaan.}

Asas pokok kewirausahaan yang perlu sekali dimasyarakatkan dan dibudidayakan pada dan oleh para pemimpin pada umumnya dan para pengusaha ( Indonesia) pada khususnya adalah:

a) Kemampuan yang kuat untuk berkarya dengan semangat mandiri ( terutama dalam bidang ekonomi )

b) Kemampuan memecahkan masalah dan mengambil keputusan termasuk keberanian mengambil resiko

c) Kemampuan berfikir dan bertindak kreatif dan inovatif

d) Kemauan dan kemampuan untuk berkarya dalam kebersamaan berlandasan etika bisnis yang sehat.

Kelima unsure hakiki kewirausahaan tersebut di atas, berkaitan erat saling menunjang satu sama lain dan harus ada setiap wirausaha yang kadar yang berbeda - beda (soetojo,2014)

\section{Konsep Pengembangan Kemandirian}

Pesantren selama ini telah terbukti tangguh mengahadapi berbagai tantangan karena kuatnya nilai ajaran yang menjadi pijakan dan prinsip kemandirian. Dalam hal pengembangan ekonomi adalah bisa memiliki jiwa dan semangat kewirausahaan ( entrepreneurship ) yang menjadi signifikan dan strategi bagi pengembangan perekonomian. Pesantren dengan demikian telah menjadi dan selalu menjadi "pelopor atau pioneer pembangunan ( ekonomi ) ummat di Indonesia.( Aziz dalam Halim: 218-219).

Pesantren memiliki tiga pilar atau potensi yaitu kiai - ulama, santri dan pendidikan sebagai sebuah magnet yang sangat potensial menjadi sumber ekonomi bagi eksistensi dan pengembangan pondok pesantren tersebut. Apabila ketiga pilar utama ini terpenuhi, pondok pesantren telah memenuhi tiga fungsi utamanya,yaitu : pertama, sebagai pusat pengkaderan pemikiran - pemikiran agama ( center of excellence). Kedua, sebagai lembaga yang mencetak sumber daya manusia ( human resource ). Ketiga, sebagai lembaga yang melakukan pemberdayaan pada masyarakat ( agent of development ).

Adapun manfaat yang dapat diperoleh dari kegiatan pemberdayaan santri di antaranya:

a) Para santri akan lebih mandiri dan lebih percaya diri, hal ini dikarenakan selain memiliki ilmu agama yang akan disampaikan ( dakwah ) kepada masyarakat, para alumni ini juga mempunyai bekal untuk memenuhi kebutuhan dunia ( ekonomi ) secara mandiri atau kebutuhan ekonomi tidak lagi menggantungkan kepada orang lain.

b) Pondok pesantren akan lebih mandiri dan cepat berkembang karena sumber dana yang selama ini hanya 
mengandalkan dari para santri dan para donator, sekarang mempunyai sumber dana baru.

c) Pondok pesantren akan lebih mendapat kepercayaan dari masyarakat, sehingga dengan demikian akan meningkatkan minat orang tua untuk mendaftarkan anak - anaknya ke pondok pesantren.

Berdasarkan data lapangan yang diperoleh Arifin (2008:9) usaha ekonomi yang dilakukan pesantren umumnya menyangkut empat hal pokok, yaitu: (a). pertanian; (b). peternakan; (c). Koperasi pesantren, dan (d).Kerajinan.

Masalah terkait pemberdayaan yang dihadapi oleh pondok pesantren di Indonesia pada umumnya adalah adalah sebagai berikut:

a) Kultur di dalam pondok yang sudah terlanjur terekam para calon santri bahwa nyantri di pondok pesantren ya belajar ilmu - ilmu agama.

b) Sumber Daya Manusia pengelola pondok pesantren terhadap usaha bisnis yang bernilai ekonomi tinggi sangat terbatas. Cendrung hanya mengelola usah - usaha tradisional.

c) Fasilitas dan peralatan yang berteknologi terbatas.

d) Dana yang terbatas.

\section{Metode Penelitian}

Jenis penelitian yang digunakan dalam penelitian ini adalah penelitian deskriptif dengan menggunakan metode kualitatif. Teknik pengumpulan data yang digunakan dalam penelitian adalah melalui partisipasi observasi, wawancara mendalam dan kajian kepustakaan. Sedangkan yang menjadi informan dalam penelitian adalah santri, kiai, masyarakat sekitar dan orang tua santri.

\section{Hasil dan Pembahasan}

Sejarah berdirinya Pondok Pesantren Nurul Hakim resminya ditetapkan tahun $1387 \mathrm{H}$. atau $1948 \mathrm{M}$, walaupun sebenarnya jauh sebelum itu telah lama dirintis oleh Al Marhum Tgh. Abdul Karim yaitu tahun 1924 dimana pada tahun tersebut beliau membangun sebuah Mushalla kecil dengan ukuran $10 \mathrm{x}$ $8 \mathrm{~m}^{2}$ sekembali beliau dari tanah suci Makkah setelah bermukim dari tahun 1919 sampai tahun 1924. Di Mushalla tersebut beliau melakukan shalat setiap waktu dan mengajar mengaji Al qur'an dan dasar-dasar agama Islam bagi masyarakat lingkungannya yaitu di Dusun Karang Bedil Desa Kediri.

Kegiatan beliau membimbing anak-anak mengaji di Mushalla tersebut terus berjalan dengan baik sampai pada akhirnya beliau harus meninggalkan pusat kegiatan tersebut pada tahun 1937 untuk melanjutkan study beliau yang kedua kalinya ke tanah suci Makkah yaitu dari tahun 1937 s/d 1938. Beliau kembali ke kampung halaman pada tahun 1939. Sekembali beliau dari tanah suci yang kedua kalinya jelas menambah pengetahuan dan pengalaman beliau untuk melanjutkan pengabdian beliau dalam bidang pengembangan ilmu-ilmu Islam dan ilmu alat seperti nahwu dan syaraf. Kehadiran beliau mengajar di Mushalla tersebut tidak sekedar membimbing anak-anak kampung Karang Bedil saja, juga menarik minat para santri yang kebetulan tinggal di Desa Kediri seperti yang tinggal di Krebung Bawak Pauk (Pondok Selaparang Sekarang) yang berada di bawah asuhan Tgh. Abdul Hafiz. Kerbung adalah bahasa sasak yang artinya pondok, karena pondok-pondok santri berada di bawah pohon mangga maka disebutlah kerbung bawak pauk (pondok selaparang sekarang). Disamping santri yang tinggal di kerbung bawak pauk juga santri-santri yang tinggal di pondok Dayen Masjid (yaitu utara Masjid) Kediri.

Di sinilah para kader pondok pesantren Nurul Hakim di tempa dan bina, terus membangun fasilitas pondok hingga sekarang. Untuk menghasil sumber daya manusia yang bermafaat baik untuk dirinya sendiri maupun untuk masyarakat pada umumnya.

\section{Tipe Kelembagaan Pondok Pesantren Nurul Hakim}

Pondok pesantren Nurul Hakim merupakan salah satu lembaga pendidikan yang berlandasan agama Islam, intraksi di dalam pondok tersebut sangat dekat antara santri, dewan santri dan kiai atau ustaz serta terdapat intraksi antara masyarakat sekita dengan santri. Santri tetap diberikan keleluasan untuk melakukan kegiatan diluar kegiatan pondok selama santri memiliki izin dari pihak pondok serta santri juga diberikan keleluasan untuk berpendapat dan pihak pondok pesantren memfasilitasi santri sesuai dengan minat dan bakatnya masing - masing untuk mengembangkan diri dan wawasannya.

Sebagaimana yang diungkapkan oleh TGH Muharrar Mahfuz selaku Wakil Pimpinan pondok pesantren berikut:

"para santri di sini bukan hanya mengkaji kitab kuning tapi juga para santri diberikan kesempatan untuk mengembangkan bakat dunianya dibidang masing - masing kemudian para santri juga diberikan kesempatan untuk berintraksi dengan masyarakat atau keluar dari pondok selama ada tujuan yang bermanfaat disertai izin dari pihak pondok pesantren".

Pondok pesantren Nurul Hakim mempunyai pimpinan pondok yang bernama TGH Sofyan Hakim namun sekarang digantikan sementara oleh TGH Muharrar Mahfuz. Beliau tidak menerapkan sistem kepemimpinan yang otoriter, beliau adalah orang yang dekat santri. Terbukti meskipun beliau sebagai pimpinan pesantren, namun disela - sela waktu kosong beliau ikut bersama santri untuk bergotong royong membersihkan pondok dan membangun beberapa bangunan pondok seperti membangun masjid dan membangun ruang belajar santri. TGH di pondok pesantren juga mampu menggerakkan masyarakat sekitar dalam baik dalam bidang pendidikan, sosial, keamanan dan budaya, contohnya pada awal pendirian pesantren tidak terlepas dari peran masyarakat sekitar.

\section{Metode Pengembangan Kemandirian kewirausahaan} pondok pesantren berbasisi santri

Metode pendidikan di pondok pesantren memadukan pengusaan sumber ajaran Islam selain mengenal ranah pengetahuan, sikap dan prilaku dalam pengajaran, sejak dini pesantren mendasarkan diri pada tiga ranah utama,yaitu kedalaman pemahaman ilmu tauhid, menanamkan karakter dan 
kecapakan terhadap ilmu agama dan keahlian ( ketrampilan ) serta aplikasinya dalam kehidupan sehari - hari.

Salah satu cara atau metode menanamkan karakter dan kecakapan keahlian atau ketrampilan yaitu memberdayakan kreativitas para santri dengan program pengembangan kemandirian dibidang ekonomi seperti kewirausahaan para santri, adapun jenis pengembangan dibidang ekonomi yaitu koperasi, agribisnis,las otomotif,konveksi dan tata busana. Contohnya jika ada pondok pesantren yang ingin mengembangan agribisnis maka langsung berkoordinasi dengan kementrian pertanian dan jika ada pondok pesantren yang ingin membuka koperasi pesantren maka langsung berkoordinasi dengan kementrian koperasi dan UMKM. Kementrian agama tidak berperan dalam program yang bersifat pemberdayaan berbasisi santri, tetapi hanya memberikan izin dan legalitas untuk pondok pesantrennya dan memberikan panduan silabus kurikulum yang mengacu kepada kurikulum di pusat dan di yayasan madrasahnya. Kemudian program dibidang pengembangan kemandirian kewirausahaan yang berbasisi santri ini juga merupakan hasil kerjasama antara para wali santri dengan pondok pesantren dan dengan pihak dinas terkait, sebagaimana yang dikatakan oleh informan sebagai berikut:

"Program pemberdayaan pengembangan kemandirian kewirausahaan santri seperti koperasi,las,agribisnis, konveksi dan tatabusana bukan hanya dari kita, akan tetapi kadang kerjasama dengan dinas terkait seperti dinas koperasi dan UMKM, dinas perdagangan, dinas pemberdayaan masyarakat , dinas pertanian serta dinas peternakan". ( wawancara dengan Ust.TGH Muzakkar, 5 Januari 2019)

Pondok pesantren nurul hakim memiliki beberapa kreativitas tersendiri dalam melaksanakan program pengembangan kemandirian kewirausahaan berbasis santri, metode yang dijalankannya sebagai diadopsi dari perguruan tinggi baik di dalam negeri maupun perguruan luar negeri. Agar pengembangan kemandirian kewirausahaan kemandirian berbasis santri dapat berjalan sesuai harapan maka pondok pesantren melakukan metode - metode berikut:

1. Dewan santri sebagai penggerak program

Pembentukan dewan santri bertujuan sebagai memberikan tataran manajemen dan semua program pengkaryaan dikoordinasikan oleh dewan santri. Sehingga dari sisi organisatorinya, santri belajar fungsi manajemen yaitu perencanaan, (planning), pengorganisasian ( organizing), pelaksanaan kebijakan (actuating) dan fungsi pengawasan ( controlling).

\section{Membentuk SMK plus Nurul Hakim}

Pembentukan SMK plus bertujuan untuk menambah wawasan dan ketrampilan para siswa terhadap bakat yang dimiliki, sehingga diharapkan lulusan dari SMK plus siap berkerja dan membuka peluang di dunia kerja.

3. Program pengabdian alumni

Santri yang lulus Madrasah Aliyah (MA) wajib mengabdi selama satu tahun di pesantren sebagai bagian dari proses pendidikan, sebagai pengikat santri agar tetap berada di jaringan hidayullah, sekaligus menambah ilmu ke tinggkat yang lebih tinggi lagi.

4. Kurikulum khas dan pendidikan pengembangan kewirausahaan

Kurikulum yang diterapkan di pondok pesantren nurul hakim yaitu dua kurikulum yaitu kurikulum yang khas pondok tersebut seperti kurikulum agama dan kurikulum umum yaitu kurikulum yang berlandasan ketrampilan yang bertujuan untuk meningkatkan pengembangan jiwa kewirausahaan para santri, seperti las,agribisnis,koperasi dan menjahit.

\section{Koordinasi Buttom Up}

Koordinasi buttom up di pondok pesantren nurul hakim telah memposisikan santri sebagai subjek program pola pengembangan kemandirian usaha berbasis santri, sehingga ada rasa memiliki dan tanggung jawab. Koordinasi buttom up tersebut sesuai dengan prinsip community development.

\section{Faktor pendorong pengembangan kemandirian} kewirasuhaan pesantren.

Program pengembangan kemandirian kewirausahaan pesantren berbasis santri di pondok pesantren Nurul Hakim dilatarbelakangi oleh tiga tuntutan utama ialah tuntutan pendidikan, tuntutan untuk meringankan beban operasional pesantren dan tuntutan dakwah. Sebagai yang di sampaikan oleh informan sebagai berikut:

...tuntutan yang pertama untuk membentuk ummat yang taat beragama. Kemudian membentuk karakter para santri, salah satunya melalui pola pendidikan kewirausahaan,sehingga diharapkan para alumni dapat menjadi wirausahawan yang mandiri serta bisa menjadi ladang dakwah di profesinya masing - masing, ( wawancara dengan Ust.TGH Muharrar Mahfuz, 7 Januari 2019)

Pertama, tuntutan pendidikan, pendidikan di pondok pesantren Nurul Hakim dirancang untuk mencapai tiga kreteria, yaitu mental spiritual, akademik dan psikomotor. Pada kreteria psikomotor, santri diharapkan terbiasa dengan kerja keras, mampu berkomunikasi secara lisan maupun tulisan, memiliki kemampuan leadership, mampu berkomunikasi dengan bahasa arab dan bahasa inggris sehari - hari.

Kedua, tuntutan untuk meringankan beban operasional pondok pesantren, salah satu hal yang penting dalam pendidikan adalah biaya, sumber penerimaan biasanya terdiri dari beberapa sumber: pemerintah, non - pemerintah maupun sumber sumber kreatif dari para penyelenggara lembaga pendidikan. Pengembangan kemandirian kewirausahaan pesantren yang berbasis santri untuk mengurangi beban operasional, sebagai yang dikatakan oleh informan sebagai berikut:

.....salah satu cara untuk mengurangi operasional dan menaikkan pendapatan pondok pesantren yaitu dengan meningkatkan dan memberdayakan santri dengan pendidikan kemandirian wirausaha, ( wawancara Ust,H.Muzakkar,15 Januari 2019)

Pimpinan pondok pesantren menargetkan 10 tahun ke depan pondok pesantren Nurul hakim akan menjadi pondok pesantren 
yang mandiri dan berkualitas tinggi terhadap alumni alumninya melalui kemandirian kewirausahaan pesantren berbasis santri, Menurut Ust,H. Muzakkar, kepala bagian operasional pendidikan pondok pesantren Nurul Hakim. Kedepannya pondok pesantren menjadi pondok yang modern, elit dan professional, oleh sebab itu kualitas sumber daya manusia dan kualitas fasilitas harus ditingkatkan.

Ketiga, tuntutan dakwah, program pengembangan kemandirian keweirausahaan pesantren berbasis santri di dorong oleh tujuan dakwah. Santri diharapkan punya ketrampilan agar lebih mudah diterima di masyarakat. Dakwah bukan hanya dalam artian ceramah, akan tetapi menyampaikan nilai - nilai Islam sesuai dengan bakat dan profesi masing - masing. Untuk mewujudkan tercapainya tuntutan dakwah maka progam diarahkan untuk memperhatikan aspek pelayanan dan bimbingan sosial keagamaan, termasuk menyiapkan da'I dan guru agama yang mempunyai sesuai dengan kebutuhan umat guna tercapainya masyarakat yag madani, sebagaimana yang diungkapkan oleh informan sebagai berikut:

...output yang diharapkan dari pondok pesantren nurul hakim ialah menjadikan santri sebagai juru tombak yang membawa dan mensyiarkan agama Islam serta membawa kebaikan,( wawancara dengan Ust.H, Muzakkar, 18 Januari 2019 ).

\section{Faktor Penghambat Pengembangan Kemandirian} Kewirausahaan pesantren Berbasis Santri.

Masalah yang terkait terhadap pola pengembangan kemandirian kewirausahaan pesantren berbasis santri yang dihadapi oleh pondok pesantren Nurul Hakim, pada umumnya sebagai berikut:

a) Sumber daya manusia ( SDM ) pengelola pondok pesantren terhadap program pengembangan kemandirian kewirausahaan pesantren berbasis santri sangat terbatas. Kualitas SDM santri hanya mampu mengelola usaha tradisional seperti peternakan dan pertanian tradisional. Usaha tersebut menghasilkan keuntungan kecil jika dibandingkan dengan beban yang harus dikeluarkan.

b) Fasilitas dan peralatan yang berteknologi serta dana yang terbatas. Keterbatasan tersebut telah menimbulkan dampak kurang berjalannya program - program yang direncanakan di antaranya: membuat kegiatan program jasa keuangan syariah. Akhirnya untuk santri putri belum ada program pembedayaan yang spesifik apalagi untuk usaha ekonomi kreatif. Program lain yang sudah diwacanakan adalah membuat kegiatan ekstrakulikuler otomotif, yang kini masih terbentur dana:

..."Sudah dirapatkan bahwa tanah atau lahan untuk kegiatan program otomotif santri sudah ada tinggal digarap lebih lanjut dan menunggu donator dari Negara timur tengah ( wawancara dengan Ust.H.Muzakkar, 20 Januari 2019)",

c) Kultur di dalam pondok pesantren yang sudah terlanjur terekam para calon santri bahwa santri di pondok hanya belajar ilmu agama. Hal ini juga terjadi di pondok pesantren nurul Hakim Kediri Lombok Barat.

d) Faktor lain yang menghambat adalah faktor manajemen yang masih kurang matang, beberapa program masih dalam tahap uji coba dan pimpinan program pun masih berganti - ganti sebagaimana di sampaikan informan berikut ini:

“...untuk program yang masih kurang manajemennya kita stop dulu sambil membenahi manajemnya, sehingga diharapkan nanti dapat berjalan dengan baik kembali. ( wawancara dengan Ust.H.Muzakkar,22 Januari 2019) ".

Masalah hambatan - hambatan yang dihadapi oleh pondok pesantren secara idealnya tidak mengorbankan idealisme dan tujuan dari program pengkaryaan itu sendiri. Maka perlu dicari strategi yang tepat untuk mengatasinya, saat ini pondok pesantren belum mampu menurunkan visinya agar dipahami bersama mulai dari pimpinan sampai akar rumput. Sehingga jika terjadi pergantian pimpinan pondok pesantren tetap mampu melanjutkan program - programnya bukan membuat program yang benar - benar baru. Kemudian jika ada perusahaan dari sisi ekternal misalnya banyaknya dana dari pemerintah maupun dari bantuan Negara -negara timur tengah dan bantuan dari perusahaan, pondok pesantren dapat menyikapinya dengan baik, jika dana itu justru menyebabkan terganggunya idealisme pondok pesantren maka dana tersebut bisa dipertimbangkan untuk ditolak.

\section{Bentuk-Bentuk Pengembangan Kemandirian Kewirausahaan Pesantren Berbasis Santri.}

Adapun bentuk - bentuk program pengembangan kemandirian kewirausahaan pesantren berbasis santri di pondok pesantren Nurul Hakim berdasarkan data lapangan secara umum diantaranya adalah sebagai berikut: Agribisnis,menjahit, las dan otomotif serta jasa keuangan syariah.

Manfaat Pengembangan Kemandirian Kewirausahaan Pesantren Berbasis Santri.

Pelaksanaan pengembangan kemandirian kewirausahaan pesantren berbasis santri bertujuan untuk memenuhi tuntutan pendidikan, ekonomi dan dakwah. Manfaatnya dirasakan baik oleh pihak pondok pesantren, santri orang tua dan masyarakat sekitar.

a) Bidang pendidikan

Bidang pendidikan pondok pesantren Nurul Hakim Kediri Lombok barat mampu menyelenggarakan pendidikan terintegrasi. Perpaduan antara kurikulum tentang agama dengan kurikulum umum, melahirkan transfer of knowledge dan kecerdasan di lapangan. Pondok pesantren Nurul Hakim Lombok Barat juga mendasarkan diri pada tiga ranah utama,yaitu: kedalam pemahaman, karakter dan kecakapan operasional.

Manfaat bagi santri di antaranya memiliki keterampilan yaitu terampil di lapangan, terampil di belakang meja dan terampil diatas mimbar seperti dialami oleh Abdullah seorang santri.

“kalau sudah pulang kampong kadang hari Juma'at dipanggil disuruh ngisi ceremah dan memberikan masukan ditengah masyarakat".( wawancara dengan Abdullah,25 januari 2019)

Selain itu, menurut Pak Anwar, kehadiran pondok pesantren telah meningkatkan pendidikan masyarakat 
sekitarnya. Banyak masyarakat di wilayah Lombok dan diluar Lombok yang menuntut ilmu di pondok pesantren Nurul Hakim.

b) Bidang ekonomi

Bidang ekonomi, pondok pesantren Nurul hakim mengkhususkan tujuan program pengembangan kemandirian kewirausahaan pesantren berbasis santri untuk meringankan beban operasional. Manfaat bagi pondok pesantren adalah biaya operasional bisa ditekan menjadi lebih rendah. Sebagaimana yang dipaparkan oleh Ust.Abdurrahman dibawah ini:

"kita pernah pake tenaga lain dan tukang dari luar, namun biaya mahal, setelah musyawarah bersama para pimpinan pondok pesantren,akhirnya kita pake santri".'(wawancara pada tanggal 27 Januari 2019)

Seiring berjalannya waktu, predikit pondok pesantren Nurul Hakim mengalami kemajuan, hal ini ditunjukkan bahwa pondok pesantren Nurul Hakim dinobatkan sebagai pondok pesantren yang modern hal ini juga disebabkan pondok pesantren Nurul Hakim menerapakan metode pendidikan yang dua arah yaitu, mengejar kebahagian di dunia dan di akherat. Kemudian pondok pesantren Nurul Hakim mampu mengadaptasi setiap perkembagan tanpa meninggalkan program - program yang sudah berjalan.

c) Bidang dakwah

Manfaat pada bidang dakwah bagi pondok pesantren Nurul Hakim di antaranya terjadinya ekspansi cepat di pondok pesantren Nurul Hakim. Di Lombok sendiri Pondok Pesantren Nurul Hakim mendapatkan kepercayaan yang lebih baik dari masyarakat terbukti dari peningkatan minat masyarakat untuk mendidik anaknya di pondok pesantren Nurul Hakim.

Menurut Pak Munawir ( Sekretaris Desa Kediri) banyak manfaat yang dirasakan masyarakat sekitar atas keberadaan pondok pesantren Nurul Hakim seperti diungkapkan berikut ini:

“......manfaat keberadaan mereka terutama bantuan mereka itu terhadap desa sangat besar sekali, tentang keagamaan, jadi masyarakat ikut ngaji gratis".( Wawancara Pada Tanggal 28 Januari )

Bagi santri manfaat pada bidang dakwah tampak pada profesionalisme yang dimiliki santri memiliki keahlian dakwah yang tepat dan dengan mentode yang diharapkan masyarakat. Santri mampu mengemban amanahnya untuk menjadi kader yang senantiasa menjalankan idealisme Islam baik untuk dirinya sendiri maupun untuk lingkungnya. Pondok pesantren Nurul Hakim selalu menjalin dan menjaga komunikasinnya dengan alumninya agar tetap tidak lepas dari jaringan pondok pesantren Nurul Hakim. Komunikasi tersebut mampu menjaga para alumni minimal untuk dirinya sendiri.

\section{Kesimpulan Dan Saran}

Kesimpulan a) Pondok pesantren Nurul Hakim merupakan institusi yang besifat total. Pendidikan di pondok pesantren Nurul Hakim memperhatikan keseimbangan kedalaman pemahaman, karakter dan kecakapan operasional.

b) Metode pengembangan kemandirian kewirausahaan pesantren berbasis yang dilakukan yaitu Dewan santri sebagai penggerak program, Membentuk SMK plus Nurul Hakim, Program pengabdian alumni, Kurikulum khas dan pendidikan pengembangan kewirausahaan dan Koordinasi Buttom Up.

c) Terdapat tuntutan untuk mendorong pengembangan kemandirian kewirausahaan pesantren berbasis santri yaitu, tuntutan pendidikan, tuntutan untuk meringankan beban operasional pesantren dan tuntutan dakwah. Pondok pesantren Nurul Hakim dituntut untuk mempertahankan idealismen Islam.

d) Bentuk - bentuk pengembangan kemandirian kewirausahaan berbasis santri yaitu adanya pendidikan kewirausahaan agribisnis, menjahit, las dan otomotif serta jasa keuangan syariah.

e) Program pengembangan kemandirian kewirausahaan pesantren berbasis santri telah berhasil mewujudkan kemandirian ekonomi pondok pesantren dan telah dirasakan manfaatnya baik oleh pesantren, santri, orang tua dan masyarakat sekitar. Namun tantangan percepatan pembangunan fasilitas dengan dukungan dana dari pihak luar menyebabkan terajadinya prioritas program.

\section{Saran}

a) Bagi pondok pesantren Nurul Hakim Kediri Lombok barat, diperlukan manajemen program yang matang. Visi dan misi pondok pesantren harus dipahami oleh seluruh civitas akademik agar program tidak hanya tergantung kepada kebijakan pimpinan yang sedang menjabat. Hindari terlalu sering membuat program yang hanya coba - coba kepada santri karena apabila terjadi kesalahan terus - menerus maka akan berakibat fatal.

b) Setelah melihat keberhasilan lulusan Pondok pesantren Nurul Hakim, masyarakat bisa mempertimbangkan untuk mendidik anaknya di pondok pesantren khususnya yang menyelenggaran program kemandirian kewirausahaan. Namun masyarakat juga melihat rekam jejak dari pondok pesantren itu sendiri karena masih banyak pondok pesantren yang belum tertib administrasi

\section{Daftar Pustaka}

Aziz,Moh.(2015). Model - model Pemberdayaan. Jakarta: LKIS Pelangi Aksara.

Armando.(2005). Pesantren dalam Perubahan Sosial Yogyakarta: Pustaka Belajar.

Halim A.,dkk(2015). Majamen Pesantren. Yogyakarta: Pustaka Pesantren. 
Huda,Saiful,dkk.(2003). Menggagas Pesantren Masa Depan; Geliat Santri Untuk Indonesia Baru.Yogyakarta:Qirtas.

Malik, Jamaludin (ed).( 2005). Pemberdayaan Pesantren Menuju Kemandirin dan Profesionalisme Santri dengan Metode Dauroh Kebudayaan. Jakarta: Pustaka Pesantren.

Malik Abdul,et.all.( 2011). Peningkatan Kemandirian Santri dan Pondok Pesantren Nurul Falah Melalui Penerapan Pengelolaan Usaha Teknologi Pertanian.Jurnal Dedikasi.8:29-36
Nazir, Moh. 2010. Metode Penelitian. Ghalia Indonesia. Jakarta Soetojo.(2013). Peningkatan Sumber Daya Manusia dan Pendidikan Kewirausahaan. Jakarta: Erlangga.

Wahid, Marzuki,Dkk.dkk (2001). Pesantren Masa Depan Wacana Pemberdayaan dan Transformasi Pesantren.Yogyakarta: Pustaka Hidayah

Yasmadi.(2014). Moderenisasi Pesantren (Edisi Revisi). Jakarta: Quantum Teaching. 